\title{
Systematic Literature Review: Media Komik dalam Pembelajaran Matematika
}

\author{
Aan Putra ${ }^{1 *}$, Ines Feltia Milenia ${ }^{2}$ \\ ${ }^{1,2}$ Institut Agama Islam Negeri Kerinci \\ *)aanputra91@gmail.com
}

\begin{abstract}
Abstrak
Media pembelajaran dapat digunakan untuk menimbulkan motivasi belajar peserta didik hingga akhirnya dapat meningkatkan kemampuan pemecahan masalah peserta didik. Penelitian ini bertujuan untuk melakukan kajian literatur terkait dengan efektivitas media komik dalam pembelajaran matematika pada pelajaran MTK di SMA/MAN. Metode penelitian yang dipilih dalam penelitian ini ialah metode SLR (Systematic Literature Review). Pengumpulan data dilakukan dengan mendokumentasi semua artikel yang memiliki penelitian serupa pada laporan penelitian ini. Artikel yang digunakan pada penelitian ini sebanyak 34 artikel jurnal nasional terakreditasi pada sinta 1 hingga sinta 4 yang diperoleh dari google scholar. Berdasarkan penelitian ini didapatkan bahwa media komik dalam pembelajaran matematika dapat meningkatkan kemampuan pemecahan masalah peserta didik. Berdasarkan kajian literatur yang dilakukan media komik dapat dikembangkan dalam pembelajaran MTK di SMA/MAN.
\end{abstract}

Kata kunci: Media Komik, Pembelajaran Matematika.

\begin{abstract}
Learning media can be used to generate student motivation to learn so that ultimately it can improve students' problem solving abilities. This study aims to conduct a literature review related to the effectiveness of comic media in mathematics learning in MTK lessons in SMA / MAN. The research method chosen in this study is the SLR (Systematic Literature Review) method. Data collection was done by documenting all articles that have similar research in this research report. The articles used in this study were 50 accredited national journal articles on Sinta 1 to Sinta 4 which were obtained from Google Scholar. Based on this research, it was found that comic media in mathematics learning can improve students' problem solving abilities. Based on literature review conducted by comic media, it can be developed in MTK learning in SMA / MAN.
\end{abstract}

Keywords: comic media, mathematics learning.

\section{Pendahuluan}

Pelajaran matematika merupakan pelajaran yang wajib dibelajarkan pada setiap jenjang sekolah (Damarsari, 2017). Matematika merupakan salah satu bidang studi yang mendukung perkembangan ilmu pengetahuan dan teknologi di era ini dan kedepan nanti (Prasetyo \& Hardjono, 2018). Pelajaran matematika tidak melulu tetang angka, tetapi jauh lebih dalam dari itu (Puspaningtyas, 2019). Ketercapaian pendidikan matematika dapat dilihat dari peserta didik mampu menyelesaikan tugas-tugas belajar matematika, peserta didik mampu menerapkan tujuan pendidikan matematika dalam kehidupan sehari-hari, mengaplikasikannya, menjadikan matematika bagian penting dalam kehidupan peserta didik. 
Penyelenggaraan Programme for International Student Assessment (PISA) tahun 2012 secara umum menyimpulkan bahwa prestasi peserta didik dibidang matematika sangat menentukan keberhasilan dan kemajuan bangsa, baik itu dalam peningkatan kualitas pendidikan maupun dalam partisipasi politik. Hal yang sangat penting diselesaikan adalah dalam pemecahan masalah, itu sebagai jantungnya dalam pembelajaran matematika. Untuk dapat membantu peserta didik dalam menemukan solusi inovatif dalam berbagai permasalahan yang dihadapi, baik di sekolah maupun dikehidupan sehari-hari salah satunya menggunakan media pembelajaran (Azhari \& Irfan, 2018).

Media pembelajaran merupakan salah satu komponen yang mempunyai peranan penting dalam pembelajaran (Putri \& Dewi, 2020). Penggunaan media pembelajaran secara tidak langsung dapat mempengaruhi semangat serta ketertarikan peserta didik dalam mengkuti kegiatan pembelajaran. Ketertarikan dan semangat peserta didik dalam proses pembelajaran diharapkan dapat meningkatkan kualitas pembelajaran sehingga hasil yang diperoleh sesuai dengan yang diharapkan. Media adalah alat bantu proses belajar mengajar untuk menyampaikan materi pembelajaran demi tercapainya tujuan pembelajaran (Karmiani, 2018). Media komik adalah media pembelajaran bahasa nonproyeksi berupa tulisan disertai gambar-gambar yang menarik yang dapat dilihat dan dibaca (Sugiartinengsih, 2018). Media pembelajaran terdapat beberapa macam, misalnya media komik, media animasi, media visual, dan sebagainnya. Media komik diharapkan dapat membantu peserta didik dalam memahami isi suatu cerita sehingga dapat menyampaikan isi cerita dengan baik (Musfiroh, 2018).

Komik merupakan cerita bergambar yang terdiri dari teks bacaan serta dialog singkat. Hal tersebut tentu akan memudahkan pembaca dalam memahami suatu cerita. Penggunaan media komik dalam proses belajar dengan peserta didik tentu akan lebih menarik minat peserta didik dan komik memiliki sifat yang sederhana (Rohmawati et al., 2017). Komik sebagai suatu bentuk kartun yang mengungkapkan karakter dan memerankan suatu cerita dalam urutan yang erat dihubungkan dengan gambar dan dirancang untuk memberikan hiburan kepada pembaca. Komik sebagai media pembelajaran merupakan alat yang berfungsi untuk menyampaikan pesan pembelajaran (Ginanjar, 2018). Pada umumnya orang membaca komik sebagai hiburan semata, akan tetapi karena semakin luasnya popularitas komik telah mendorong banyak guru bereksperimen dengan medium ini untuk maksud pembelajaran (Ramadhani, 2019). Penggunaan media komik dalam proses belajar dengan peserta didik tentu akan lebih 
menarik minat peserta didik dan dapat meningkatkan kemampuan pemecahan masalah siswa.

\section{Metode Penelitian}

Metode yang digunakan dalam penelitian ini adalah metode SLR (Systematic Literature Review). Metode ini peneliti lakukan dengan mengidentifikasi, mengkaji, mengevaluasi serta menafsirkan semua penelitian yang tersedia. Dengan metode ini peneliti melakukan review dan mengidentifikasi jurnal-jurnal secara sistematis yang pada setiap prosesnya mengikuti langkah-langkah yang telah ditetapkan (Triandini, Jayanatha, Indrawan, Putra, \& Iswara, 2019).

Berdasarkan dari tahapan-tahapan di atas maka peneliti mencari artikel jurnal yang dengan kata kunci efektivitas media komik dalam pembelajaran matematika. Pengumpulan data dilakukan dengan mendokumentasi semua artikel yang diperoleh pada laporan penelitian ini. Artikel yang digunakan pada penelitian ini sebanyak 15 artikel jurnal nasional terakreditasi pada sinta 1 hingga sinta 4 yang diperoleh dari google scholar. Artikel yang dipilih adalah artikel yang memiliki penelitian serupa lalu artikel dianalisis dan dirangkum. Hasil penelitian kemudian dijadikan kedalam satu pembahasan yang utuh pada artikel ini.

\section{Hasil dan Pembahasan}

Hasil data penelitian yang dimasukkan dalam kajian literatur ini adalah analisis dan rangkuman dari artikel yang didokumentasi terkait dengan efektivitas media komik, pembelajaran matematika dan pemecahan masalah, yang disajikan pada Tabel 1, Tabel 2, dan Tabel 3. 
Tabel 1. Tabel Hasil Penelitian Terhadap Efektivitas Media Komik

\begin{tabular}{|c|c|c|}
\hline Peneliti & Judul Penelitian & Hasil Penelitian \\
\hline $\begin{array}{l}\text { (Riwanto \& } \\
\text { Wulandari, } \\
\text { 2018) }\end{array}$ & $\begin{array}{l}\text { Efektivitas } \\
\text { Penggunaan Media } \\
\text { Komik Digital } \\
\text { (Cartoon Story } \\
\text { Maker) dalam } \\
\text { pembelajaran Tema } \\
\text { Selalu Berhemat } \\
\text { Energi. } \\
\end{array}$ & $\begin{array}{l}\text { Penelitian ini menngunakan media komik } \\
\text { digital dengan menggunakan tema selalu } \\
\text { berhemat energi. Berdasarkan penelitian } \\
\text { menunjukkan bahwa penggunaan komik } \\
\text { digital yang dibuat dengan software } \\
\text { Cartoon Story Maker dapat meningkatkan } \\
\text { efektivitas pembelajaran pada materi tema } \\
\text { selalu berhemat energi. }\end{array}$ \\
\hline $\begin{array}{l}\text { (Fadella \& } \\
\text { Prabowo, } \\
\text { 2018) }\end{array}$ & $\begin{array}{l}\text { Keefektifan Problem- } \\
\text { Based Learning } \\
\text { Berbantuan Komik } \\
\text { Matematika terhadap } \\
\text { Kemampuan } \\
\text { Pemecahan Masalah } \\
\text { dan Rasa Ingin Tahu } \\
\text { Siswa }\end{array}$ & $\begin{array}{l}\text { Penelitian ini untuk melihat efektif } \\
\text { problem based learning berbantuan media } \\
\text { komik. Hasil penelitian ini menunjukan } \\
\text { bahwa Kemampuan pemecahan masalah } \\
\text { pada kelas eksperimen mencapai } \\
\text { ketuntasan klasikal dan rata-rata } \\
\text { kemampuan pemecahan masalah siswa } \\
\text { kelas eksperimen lebih tinggi dari kelas } \\
\text { control. }\end{array}$ \\
\hline $\begin{array}{l}\text { (Subroto, } \\
\text { Qohar, \& } \\
\text { Dwiyana, } \\
\text { 2020) }\end{array}$ & $\begin{array}{l}\text { Efektivitas } \\
\text { Pemanfaatan Komik } \\
\text { sebagai Media } \\
\text { Pembelajaran } \\
\text { Matematika }\end{array}$ & $\begin{array}{l}\text { Penelitian ini untuk melihat efektif } \\
\text { pemanfaatan media komik. Penelitian ini } \\
\text { bertujuan untukmengetahui efektivitas } \\
\text { pemanfaatan komik sebagai media dalam } \\
\text { pembelajaran Matematika. Berdasarkan } \\
\text { hasil penelitian menunjukkan bahwa } \\
\text { persentase hasil data angket pemilihan } \\
\text { media diperoleh sebanyak 55\% siswa } \\
\text { memilih menggunakan komik sebagai } \\
\text { media pembelajarandan persentase hasil } \\
\text { angket respon siswa diperoleh } 88,58 \% \\
\text { respons siswa positif terhadap penggunaan } \\
\text { komik. }\end{array}$ \\
\hline $\begin{array}{l}\text { (Mujawal, } \\
\text { Bani, \& Nani, } \\
\text { 2018) }\end{array}$ & $\begin{array}{l}\text { Penggunaan Media } \\
\text { Komik dalam } \\
\text { Pembelajaran } \\
\text { Matematika untuk } \\
\text { Meningkatkan } \\
\text { Motivasi dan Hasil } \\
\text { Belajar Siswa pada } \\
\text { Materi SPLDV }\end{array}$ & $\begin{array}{l}\text { Penelitian ini menggunakan media komik } \\
\text { berfokus pada materi SPLDV. Hasil } \\
\text { penelitian menunjukkan bahwa hasil } \\
\text { belajar siswa setelah menggunakan media } \\
\text { komik dalam pembelajaran diperoleh } 20 \% \\
\text { siswa dalam kualifikasi baik sekali, } 48 \% \\
\text { siswa dalam kualifikasi baik, } 32 \% \text { siswa } \\
\text { dalam kualifikasi cukup, dan tidak terdapat } \\
\text { siswa dalam kualifikasi kurang dan gagal. }\end{array}$ \\
\hline $\begin{array}{l}\text { (Suparmi, } \\
\text { 2018) }\end{array}$ & $\begin{array}{l}\text { Penggunaan Media } \\
\text { Komik Dalam } \\
\text { Pembelajaran IPA Di } \\
\text { Sekolah }\end{array}$ & $\begin{array}{l}\text { Penelitian ini menggunakan media komik. } \\
\text { Hasil penelitian menunjukkan bahwa } \\
\text { penggunaa media Komik dapat } \\
\text { meningkatkan hasil belajar. }\end{array}$ \\
\hline
\end{tabular}


Tabel 2. Tabel Hasil Penelitian Terhadap Pembelajaran Matematika

\begin{tabular}{|c|c|c|}
\hline Peneliti & Judul Penelitian & Hasil Penelitian \\
\hline $\begin{array}{l}\text { (Aji \& } \\
\text { Mampouw, } \\
\text { 2019) }\end{array}$ & $\begin{array}{l}\text { Pengembang } \\
\text { Komik Sebagai } \\
\text { Media } \\
\text { Pembelajaran } \\
\text { Matematika Materi } \\
\text { Aljabar }\end{array}$ & $\begin{array}{l}\text { Penelitian ini mengembangkan komik yang } \\
\text { berfokus pada materi aljabar. Bertujuan } \\
\text { untuk mendeskripsikan hasil pengembangan } \\
\text { komik petualangan alja yang dapat } \\
\text { meningkatkan hasil belajar siswa pada } \\
\text { materi aljabar. Hasil penelitian } \\
\text { menunjukkan materi aljabar pada media } \\
\text { komik petualangan alja terdiri dari dasar- } \\
\text { dasar aljabar dan operasi hitung aljabar. } \\
\text { Media pembelajaran komik petualangan alja } \\
\text { telah melewati tahapan validasi media dan } \\
\text { konten serta dinyatakan valid. }\end{array}$ \\
\hline $\begin{array}{l}\text { (Cahirati, Makur, } \\
\text { \& Fedi, 2020) }\end{array}$ & $\begin{array}{l}\text { Analisis Kesulitan } \\
\text { Belajar Siswa } \\
\text { dalam Pembelajaran } \\
\text { Matematika yang } \\
\text { Menggunakan } \\
\text { Pendekatan PMRI }\end{array}$ & $\begin{array}{l}\text { Penelitian ini menganalisis kesulitan belajar } \\
\text { pada pembelajaran matematika. Hasil dari } \\
\text { penelitian ini adalah jenis kesulitan belajar } \\
\text { yang dialami siswa, yaitu kesulitan dalam } \\
\text { memahami konsep sistem persamaan dua } \\
\text { variabel dan tiga variabel, kesulitan } \\
\text { menghitung angka dalam sistem persamaan } \\
\text { linear untuk dua variabel dan tiga variabel, } \\
\text { dan kesulitan memecahkan masalah dalam } \\
\text { masalah cerita dalam materi SPLDV dan } \\
\text { SPLTV. }\end{array}$ \\
\hline $\begin{array}{l}\text { (Ahmad \& } \\
\text { Nasution, 2018) }\end{array}$ & $\begin{array}{l}\text { Analisis Kualitatif } \\
\text { Kemampuan } \\
\text { Komunikasi } \\
\text { Matematis Siswa } \\
\text { Yang Diberi } \\
\text { Pembelajaran } \\
\text { Matematika } \\
\text { Realistik } \\
\end{array}$ & $\begin{array}{l}\text { Penelitian ini menganalisis kemampuan } \\
\text { komunikasi dalam pembelajaran } \\
\text { matematika. Hasil penelitian menunjukkan } \\
\text { bahwa kemampuan komunikasi matematis } \\
\text { siswa 22,5\% kategori tinggi, } 37,5 \% \text { kategori } \\
\text { sedang dan 40\% kategori rendah. }\end{array}$ \\
\hline $\begin{array}{l}\text { (Ratumanan \& } \\
\text { Tetelepta, 2019) }\end{array}$ & $\begin{array}{l}\text { Analisis } \\
\text { Pembelajaran } \\
\text { Matematika } \\
\text { Berdasarkan } \\
\text { Kurikulum } 2013 \\
\text { pada SMA } \\
\text { NEGERI } 1 \text { Masohit }\end{array}$ & $\begin{array}{l}\text { Penelitian ini menganalisis pembelajaran } \\
\text { matematika. Hasil penelitian adalah Rata- } \\
\text { rata kualitas RPP ketiga guru adalah } 67,01 \\
\text { dan masuk dalam kategori cukup }(\mathrm{C}) \text { dan } \\
\text { Guru belum mampu melaksanakan } \\
\text { pembelajaran sebagai bentuk implementasi } \\
\text { kurikulum } 2013 \text { secara baik. }\end{array}$ \\
\hline $\begin{array}{l}\text { (Asdarina \& } \\
\text { Arwinda, 2020) }\end{array}$ & $\begin{array}{l}\text { Analisis } \\
\text { Implementasi } \\
\text { Pendidikan } \\
\text { Karakter dalam } \\
\text { Proses } \\
\text { Pembelajaran } \\
\text { Matematika }\end{array}$ & $\begin{array}{l}\text { Penelitian ini menganalisis Implementasi } \\
\text { Pendidikan Karakter dalam Pembelajaran } \\
\text { Matematika. Hasil penelitian ini } \\
\text { menunjukan bahwa proses pengembangan } \\
\text { karakter yang terjadi di lingkungan sekolah } \\
\text { diantaranya adalah dengan memberikan } \\
\text { teladan, teguran, dan nasihat. }\end{array}$ \\
\hline
\end{tabular}


Tabel 3. Tabel Hasil Penelitian Terhadap Pemecahan Masalah

\begin{tabular}{|c|c|c|}
\hline Peneliti & Judul Penelitian & Hasil Penelitian \\
\hline $\begin{array}{l}\text { (Nurfitriyanti, } \\
\text { Rosa, \& } \\
\text { Patimah, 2020) }\end{array}$ & $\begin{array}{l}\text { Adversity Quotient } \\
\text { dan Locus of } \\
\text { Control Serta } \\
\text { Pengaruhnya } \\
\text { Terhadap } \\
\text { Kemampuan } \\
\text { Pemecahan } \\
\text { Masalah } \\
\text { Matematika }\end{array}$ & $\begin{array}{l}\text { Penelitian ini menggunakan Adversity } \\
\text { Quotient dan Locus of Control. Hasil } \\
\text { penelitian menunjukkan terdapat pengaruh } \\
\text { yang signifikan antara adversity quotient dan } \\
\text { locus of control terhadap kemampuan } \\
\text { pemecahan masalah matematika secara } \\
\text { bersama-sama sebesar } 31,9 \% \text { dan terdapat } \\
\text { pengaruh yang signifikan antara adversity } \\
\text { quotient terhadap kemampuan pemecahan } \\
\text { masalah matematika sebesar } 12,5 \% \text {; }\end{array}$ \\
\hline $\begin{array}{l}\text { (Anugrah, } \\
\text { Dewi, Sudiarta, } \\
\text { \& Suweken, } \\
\text { 2020) }\end{array}$ & $\begin{array}{l}\text { Pengembangan } \\
\text { Perangkat Model } \\
\text { Pembelajaran Tutor } \\
\text { Sebaya Berbantuan } \\
\text { Komik Matematika } \\
\text { untuk } \\
\text { Meningkatkan } \\
\text { Kemampuan } \\
\text { Pemecahan } \\
\text { Masalah } \\
\text { Matematika Siswa }\end{array}$ & $\begin{array}{l}\text { Penelitian ini mengembangkan perangkat } \\
\text { model pembelajaran tutor sebaya berbantuan } \\
\text { komik matematika. Hasil penelitian ini } \\
\text { menunjukan bahwa skor kemampuan } \\
\text { pemecahan masalah siswa pada uji coba } \\
\text { lapangan I adalah } 79,81 \text { (kategori baik) dan } \\
\text { meningkat menjadi sebesar } 81,5 \text { (kategori } \\
\text { baik) pada uji coba lapangan II. }\end{array}$ \\
\hline (Kurniati, 2017) & $\begin{array}{l}\text { Pembelajaran } \\
\text { Kontekstual Open } \\
\text { Ended Problem } \\
\text { Solving dengan } \\
\text { Komik Matematika } \\
\text { untuk } \\
\text { Meningkatkan } \\
\text { Keterampilan } \\
\text { Pemecahan } \\
\text { Masalah }\end{array}$ & $\begin{array}{l}\text { Penelitian ini menggunakan media komik } \\
\text { matematika untuk meningkatkan keterampilan } \\
\text { pemecahan masalah. Hasil penelitian } \\
\text { menunjukkan bahwa perangkat yang } \\
\text { dikembangkan telah dinyatakan valid oleh } \\
\text { validator dengan skor rata-rata } 4,13 \text { untuk } \\
\text { silabus, } 4,11 \text { untuk RPP, } 4,20 \text { untuk LKS, } 4,18 \\
\text { untuk komik dan pembelajaran praktis ditandai } \\
\text { dengan respon positif siswa dan kemampuan } \\
\text { guru baik. }\end{array}$ \\
\hline $\begin{array}{l}\text { (Gumilang \& } \\
\text { Indarini, 2019) }\end{array}$ & $\begin{array}{l}\text { Pengembangan } \\
\text { Media Komik } \\
\text { dengan Model } \\
\text { Problem Posing } \\
\text { untuk } \\
\text { Meningkatkan } \\
\text { Kemampuan } \\
\text { Pemecahan } \\
\text { Masalah } \\
\text { Matematika }\end{array}$ & $\begin{array}{l}\text { Penelitian ini mengembangkan media komik } \\
\text { dengan model problem posing. Hasil penelitian } \\
\text { menunjukkan bahwa media komik dengan } \\
\text { model problem posing untuk meningkatkan } \\
\text { kemampuan pemecahan maalah matematika. }\end{array}$ \\
\hline $\begin{array}{l}\text { (Rigusti \& } \\
\text { Pujiastuti, } \\
\text { 2020) }\end{array}$ & $\begin{array}{l}\text { Analisis } \\
\text { kemampuan } \\
\text { pemecahan } \\
\text { masalah } \\
\text { matematika }\end{array}$ & $\begin{array}{l}\text { Penelitian ini menganalisis kemampuan } \\
\text { pemecahan masalah matematika. Penelitian ini } \\
\text { bertujuan untuk mendeskripsikan kemampuan } \\
\text { pemecahan masalah ditinjau dari motivasi } \\
\text { belajar matematika siswa. Hasil penelitian }\end{array}$ \\
\hline
\end{tabular}




\begin{tabular}{|c|c|c|}
\hline & $\begin{array}{l}\text { ditinjau dari } \\
\text { motivasi belajar } \\
\text { matematika siswa }\end{array}$ & $\begin{array}{l}\text { menunjukkan nilai rata-rata kemampuan } \\
\text { pemecahan masalah siswa yang memiliki } \\
\text { motivasi tinggi yaitu } 75.6 \text {, Siswa dengan } \\
\text { motivasi sedang rata-rata kemampuan } \\
\text { pemecahan masalah matematika 70.7, dan rata- } \\
\text { rata kemampuan pemecahan masalah untuk } \\
\text { siswa dengan motivasi rendah yaitu 59,4. }\end{array}$ \\
\hline $\begin{array}{l}\text { (A. A. Nugroho } \\
\text { \& Dwijayanti, } \\
\text { 2019) }\end{array}$ & $\begin{array}{l}\text { Analisis } \\
\text { Kemampuan } \\
\text { Pemecahan } \\
\text { Masalah } \\
\text { Mahasiswa Calon } \\
\text { Guru Matematika } \\
\text { Pada Mata Kuliah } \\
\text { Program Linier }\end{array}$ & $\begin{array}{l}\text { Penelitian ini menganalisis kemampuan } \\
\text { pemecahan masalah matematika. Hasil } \\
\text { penelitian ini, subjek dapat memahami } \\
\text { permasalahan dengan cara mengidentifikasi } \\
\text { informasi-informasi yang muncul pada } \\
\text { permasalahan dan menentukan menggunakan } \\
\text { metode simplek sebagai cara penyelesaiannya } \\
\text { dengan mengubah soal cerita menjadi model } \\
\text { matematikanya terlebih dahulu }\end{array}$ \\
\hline $\begin{array}{l}\text { (Hafidz, } \\
\text { Kusumaningsih, } \\
\text { \& Aini, 2019) }\end{array}$ & $\begin{array}{l}\text { Analisis } \\
\text { Kemampuan } \\
\text { Pemecahan } \\
\text { Masalah } \\
\text { Matematika } \\
\text { Ditinjau dari } \\
\text { Motivasi Belajar } \\
\text { Siswa Berdasarkan } \\
\text { Gender }\end{array}$ & $\begin{array}{l}\text { Penelitian ini menganalisis kemampuan } \\
\text { pemecahan masalah matematika berdasarkan } \\
\text { gender. Hasil penelitian ini adalah kemampuan } \\
\text { pemecahan masalah siswa laki-laki dengan } \\
\text { kemampuan koginif sedang dan motivasi } \\
\text { belajar tinggi mampu melaksanakan } \\
\text { kemampuan pemecahan masalah dengan baik } \\
\text { pada indikator memahami masalah, namun } \\
\text { subjek kurang mampu pada indikator membuat } \\
\text { rencana, melaksanakan rencana, dan } \\
\text { memeriksa kembali }\end{array}$ \\
\hline $\begin{array}{l}\text { (Rismen, } \\
\text { Juwita, \& } \\
\text { Devinda, 2020) }\end{array}$ & $\begin{array}{l}\text { Analisis } \\
\text { Kemampuan } \\
\text { Pemecahan } \\
\text { Masalah } \\
\text { Matematika Siswa } \\
\text { Ditinjau dari Gaya } \\
\text { Kognitif Impulsif }\end{array}$ & $\begin{array}{l}\text { Penelitian ini menganalisis kemampuan } \\
\text { pemecahan masalah matematika berdasarkan } \\
\text { Gaya Kognitif Impulsif. Tujuan penelitian ini } \\
\text { adalah untuk mendeskripsikan kemampuan } \\
\text { pemecahan masalah matematis siswa yang } \\
\text { memiliki gaya kognitif impulsif. Hasil } \\
\text { penelitian diperoleh kemampuan pemecahan } \\
\text { masalah siswa yang memiliki gaya kognitif } \\
\text { impulsif lebih dominan berada pada kriteria } \\
\text { rendah. }\end{array}$ \\
\hline $\begin{array}{l}\text { (Rahmah, } \\
\text { Puspitorini, \& } \\
\text { Musthafa, } \\
\text { 2020) }\end{array}$ & $\begin{array}{l}\text { Analisis Kesulitan } \\
\text { Siswa dalam } \\
\text { Pemecahan } \\
\text { Masalah } \\
\text { Matematika Kelas } \\
\text { XI IPA SMAN } 2 \\
\text { Sumenep }\end{array}$ & $\begin{array}{l}\text { Penelitian ini menganalisis kemampuan } \\
\text { pemecahan masalah matematika. Hasil } \\
\text { penelitian menunjukkan bahwa siswa dengan } \\
\text { kemampuan tinggi, sedang dan rendah } \\
\text { mengalami kesulitan dalam memeriksa } \\
\text { kembali hasil yang diperoleh karena tidak } \\
\text { terbiasa mengecek serta menuliskan } \\
\text { kesimpulan dari apa yang ditanya pada soal. }\end{array}$ \\
\hline $\begin{array}{l}\text { (Sulistiawati, } \\
\text { Arsyad, \& } \\
\text { Minggi, 2019) }\end{array}$ & $\begin{array}{l}\text { Deskripsi } \\
\text { Penalaran Siswa } \\
\text { dalam Pemecahan } \\
\text { Masalah }\end{array}$ & $\begin{array}{l}\text { Penelitian ini menggunakan kemampuan } \\
\text { pemecahan masalah matematika berfokus pada } \\
\text { materi Barisan dan Deret. Hasil penelitian } \\
\text { diperoleh bahwa proses penalaran siswa yang }\end{array}$ \\
\hline
\end{tabular}




\begin{tabular}{|c|c|c|}
\hline & $\begin{array}{l}\text { Matematika pada } \\
\text { Pokok Bahasan } \\
\text { Barisan dan Deret } \\
\text { Ditinjau dari } \\
\text { Kemampan Awal }\end{array}$ & $\begin{array}{l}\text { berkemampuan tinggi yaitu mengaitkan konsep } \\
\text { dan pengetahuan yang dimilikinya, } \\
\text { mengumpulkan bukti dengan menyebutkan } \\
\text { hal-hal yang diketahui dan ditanyakan, } \\
\text { mengaitkan rumus yang sudah dimiliki dengan } \\
\text { masalah yang dihadapi, mengidentifikasi } \\
\text { konsep yang digunakan untuk memecahkan } \\
\text { masalah, mengungkapkan alasan dalam } \\
\text { menjelaskanlangkah-langkah dalam } \\
\text { melaksanakan pemecahan masalah. }\end{array}$ \\
\hline $\begin{array}{l}\text { (Mery, Hidayat, } \\
\text { \& Ihsan, 2020) }\end{array}$ & $\begin{array}{l}\text { Desain } \\
\text { Pembelajaran } \\
\text { Model Problem- } \\
\text { Based Learning } \\
\text { Terkait } \\
\text { Kemampuan } \\
\text { Berpikir Kreatif } \\
\text { Matematis dan } \\
\text { Adversity Quotient } \\
\text { Peserta Didik. }\end{array}$ & $\begin{array}{l}\text { Penelitian ini menggunakan Desain } \\
\text { Pembelajaran Model Problem-Based Learning. } \\
\text { Hasil penelitian ini diperoleh adalah desain } \\
\text { (awal) pembelajaran model PBL dengan materi } \\
\text { barisan dan deret. Dalam mengajar materi } \\
\text { barisan aritmatika diawali dengan diberikannya } \\
\text { apersepsi, materi prasyarat yaitu definisi } \\
\text { fungsi, pendidik dapat menyajikan diagram } \\
\text { panah yang merepresentasikan fungsi dari } \\
\text { himpunan bilangan asli ke sebarang himpunan. } \\
\text { Kegiatan berlanjut dengan orientasi peserta } \\
\text { didik pada masalah dengan tujuan memotivasi } \\
\text { peserta didik untuk terlibat dalam pemecahan } \\
\text { masalah yang diberikan. }\end{array}$ \\
\hline $\begin{array}{l}\text { (Dewi \& Septa, } \\
\text { 2019) }\end{array}$ & $\begin{array}{l}\text { Peningkatan } \\
\text { kemampuan } \\
\text { pemecahan } \\
\text { masalah dan } \\
\text { disposisi matematis } \\
\text { siswa dengan } \\
\text { pembelajaran } \\
\text { berbasis masalah. }\end{array}$ & $\begin{array}{l}\text { Penelitian ini menggunakan kemampuan } \\
\text { pemecahan masalah matematika. Hasil } \\
\text { penelitian ini adalah Berdasarkan analisis data, } \\
\text { diperoleh bahwa peningkatan kemampuan } \\
\text { pemecahan masalah siswa yang memperoleh } \\
\text { PBM lebih tinggi dari siswa yang memperoleh } \\
\text { pembelajaran konvensional. Peningkatan } \\
\text { disposisi matematis siswa yang memperoleh } \\
\text { PBM lebih tinggi dari siswa yang memperoleh } \\
\text { pembelajaran konvensional. }\end{array}$ \\
\hline
\end{tabular}

\section{Media Komik}

Media yang menarik tidak akan memberikan tekanan kepada peserta didik dalam belajar sehingga mereka akan tetap nyaman saat belajar tanpa adanya unsur keterpaksaan. Salah satu bentuk media itu adalah media komik pembelajaran. Mengapa komik? Karena peserta didik dan sebagaimana orang dewasa juga menyukai komik. Komik mempunyai sifat sederhana, jelas dan mudah dipahami sehingga menjadi media yang informatif dan edukatif (Ramdhani, Magfirah, \& Hambali, 2020). Media yang digunakan guru terbatas menggunakan media buku pelajaran, hal ini kurang menarik bagi siswa sehingga motivasi peserta didik dalam membaca materi pelajaran sangat rendah, sehingga perlu adanya media 
yang mampu meningkatkan minat baca sehingga siswa dapat meningkat kemampuan pemecahan masalah adalah media komik (Winara \& Haniyyah, 2019).

Komik merupakan media komunikasi visual yang unik karena menggunakan teks dan gambar dalam bentuk yang kreatif serta mempunyai kekuatan untuk menyampaikan informasi secara popular dan mudah dimengerti (Meidyawati \& Ws, 2018). Komik dapat membuat pembaca mudah memahami alur cerita karena dibuat dengan bahasa keseharian sehingga mudah dimengerti (Dewi Nur Aziza, Elok Sudibyo, 2019). Komik juga dibuat dengan gambar-gambar yang menarik sehingga menarik pembaca untuk membaca teks dalam cerita (Khasanah, Nurhidayat, \& Ferawati, 2019). Adapun jenis-jenis komik antara lain adalah: 1) Kartun/karikatur (Cartoon), 2) Komik potongan (Comic Strip), 3) Buku komik (Comic Book), 4) Komik tahunan (Comic annual), 5) Komik Online (Web Comic). Tujuan media pembelajaran komik untuk memberikan nuansa baru dalam pembelajaran, selain itu penggunaan komik dapat meningkatkan minat siswa dalam pembelajaran dan lebih mudah mengingat materi pelajaran yang diajar (Mulyati, 2016).

Berdasarkan hasil penelitian pada Tabel 1, Tabel 2, dan Tabel 3. Penelitian yang telah dilaksanakan mendapatkan respon positif dari peserta didik. Namun terdapat juga kekurangan dari media komik tersebut. Adapun kekurangannya adalah 1) Kemudahan orang memahami komik membuat malas membaca, sehingga menyebabkan penolakan atas buku yang tidak bergambar, 2) Ditinjau dari segi bahasa komik terkesan menggunakan bahasa kotor yang kurang dapat di pertanggung jawabkan, 3) Banyak aksi yang menonjolkan kekerasan (Perverted), 4) Banyak adegan percintaan yang menonjol (B. S. Nugroho, 2018).

Hal yang perlu diperhatikan dalam efektivitas media pembelajaran komik adalah 1) Media komik sebagai perbendaharaan kata-kata pembacanya, 2) Mempermudah peserta didik menangkap hal-hal atau rumusan yang abstrak, 3) Mengembangkan minat baca peserta didik dan salah satu bidang studi yang lain, 4) Seluruh jalan cerita komik pada menuju satu hal yakni kebaikan atau studi yang lain. Adapun beberapa alasan menggunakan komik dalam proses belajar mengajar di kelas, diantaranya yaitu: 1) Tingginya minat siswa terhadap komik, 2) Murah dan mudah didapatkan, 3) Kosakata yang digunakan tidak sulit sehingga mudah dibaca oleh siswa, 4) Melibatkan siswa dalam diskusi untuk membahas konten-konten yang ada di dalam komik. 


\section{Pembelajaran Matematika}

Matematika berasal dari bahasa latin manthanein atau mathemayang berarti 'belajar atau hal yang dipelajari', sedang dalam bahasa Belanda disebut wiskunde atau 'ilmu pasti' (Nuraeni, Azwar Uswatun, \& Nurasiah, 2020). Di Indonesia, matematika pernah disebut ilmu pasti. Mengapa ia disebut ilmu pasti? Jawaban pertanyaan terakhir berkait dengan istilah penalaran (reasoning). Dikenal dua macam penalaran, yaitu penalaran induktif (induksi) dan penalaran deduktif (deduksi). Matematika disebut ilmu deduktif, sebab dalam matematika tidak menerima generalisasi yang berdasarkan pada observasi, eksperimen, coba-coba (induktif) seperti halnya ilmu pengetahuan alam dan ilmu-ilmu pengetahuan umumnya. Kebenaran generalisasi matematika harus dapat dibuktikan secara deduktif (Mufarizuddin, 2018).

Matematika adalah bahasa symbol; ilmu deduktif; ilmu tentang pola keteraturan, dan struktur yang terorganisasi, mulai dari unsur yang tidak didefinisikan, ke unsur yang yang didefinisikan, ke aksioma atau postulat, dan akhirnya ke dalil. Hakikat matematika menurut Soedjadi, yaitu memiliki obyek tujuan abstrak, bertumpu pada kesepakatan, dan pola piker yang deduktif.

Matematika sebagai ilmu dasar, dewasa ini telah berkembang sangat pesat baik meteri maupun kegunaanya. Sehingga dalam perkembangan atau pembelajaranya di sekolah harus memperhatikan perkembangan-perkembangannya, baik di masa lalu, masa sekarang maupun masa depan. Matematika sekolah merupakan matematika yang diajarkan di sekolah yang terdiri atas bagian-bagian matematika yang dipilih guna menumbuhkembangkan kemampuan-kemampuan untuk menjadi pribadi serta berpadu pada perkembangan IPTEK (Hardianto \& Baharuddin, 2019).

Berhubungan dengan definisi pembelajaran dapat disimpulkan bahwa pembelajaran matematika merupakan suatu proses kerjasama, tidak hanya menitikberatkan pada kegiatan guru atau kegiatan peserta didik saja, akan tetapi guru dan peserta didik secara bersamasama dalam memanfaatkan segala potensi dan sumber belajar matematika yang ada untuk mencapai tujuan pembelajaran matematika yang telah ditentukan. 


\section{Simpulan}

Berdasarkan hasil dan pembahasan yang telah dipaparkan di atas, maka dapat ditarik kesimpulan bahwa media komik dapat meningkatkan kemampuan pemecahan masalah peserta didik. Berdasarkan hasil dan pembahasan penelitian terhadap efektivitas media komik ini terdapat respon positif yang diberikan oleh peserta didik. Diharapkan dalam penelitian selanjutnya peneliti dapat menerapkan kajian ini pada efektivitas media komik pada pembelajaran Matematika di SMA/MAN.

\section{Referensi}

Ahmad, M., \& Nasution, D. P. (2018). Analisis Kualitatif Kemampuan Komunikasi Matematis Siswa Yang Diberi Pembelajaran Matematika Realistik. Jurnal Gantang, 3(2), 83-95. https://doi.org/10.31629/jg.v3i2.471

Aji, W. P., \& Mampouw, H. L. (2019). Pengembangan Komik Sebagai Media Pembelajaran Matematika Materi Aljabar. Prosiding Sendika, 5(1), 404-410.

Anugrah, P., Dewi, C., Sudiarta, I. G. P., \& Suweken, G. (2020). Pengembangan Perangkat Model Pembelajaran Tutor Sebaya Berbantuan Komik Matematika untuk Meningkatkan Kemampuan Pemecahan Masalah Matematika Siswa. 14(1), 106-118.

Asdarina, O., \& Arwinda, N. (2020). Analisis Implementasi Pendidikan Karakter dalam Proses Pembelajaran Matematika. MATHEMA JOURNAL, 2(1), 1-11.

Azhari, B., \& Irfan, A. (2018). Model-eliciting activities dalam menganalisis kreativitas pemecahan masalah matematika pada mahasiswa pendidikan matematika di PTKIN aceh. Sereal Untuk, 51(1), 51.

Cahirati, P. E. P., Makur, A. P., \& Fedi, S. (2020). Analisis Kesulitan Belajar Siswa dalam Pembelajaran Matematika yang Menggunakan Pendekatan PMRI Mosharafa: Jurnal Pendidikan Matematika adalah Realistic Matematic Education Mosharafa: Jurnal Pendidikan Matematika. 9.

Damarsari, R. (2017). Efektivitas penggunaan media patama terhadap prestasi belajar matematika siswa berkesulitan belajar matematika kelas II di SDN bangurejo 2 yogyakarta. Nursing Research, 32(4), 253-255. https://doi.org/10.1097/00006199198307000-00018

Dewi Nur Aziza, Elok Sudibyo, A. L. (2019). Penggunaan Media Pembelajaran Komik pada Materi Getaran untuk Meningkatkan Hasil Belajar Siswa. Jurnal Pendidikan Sains, 7 No.2, 187-19. $\quad$ Retrieved from https://jurnalmahasiswa.unesa.ac.id/index.php/pensa/article/view/28096

Dewi, P. S., \& Septa, H. W. (2019). Peningkatan kemampuan pemecahan masalah dan disposisi matematis siswa dengan pembelajaran berbasis masalah. MATHEMA JOURNAL, 1(1), 31-39.

Fadella, E. F., \& Prabowo, A. (2018). Keefektifan Problem-Based Learning Berbantuan Komik Matematika terhadap Kemampuan Pemecahan Masalah dan Rasa Ingin Tahu Siswa. Prisma, Prosiding Seminar Nasional Matematika, 1, 77-86.

Ginanjar, G. G. (2018). Penggunaan Media Komik dalam Keterampilan Menulis Laporan. Jurnal Ilmiah Pendidikan Guru Sekolah Dasar, 5(2), 372-379.

Gumilang, M. R., \& Indarini, E. (2019). Pengembangan Media Komik dengan Model Problem Posing untuk Meningkatkan Kemampuan Pemecahan Masalah Matematika matematis merupakan salah satu secara interaktif, inspiratif, menyenang- 
melakukan penguasaan bahan dan materi. 3(2), 185-196.

Hafidz, A. A., Kusumaningsih, W., \& Aini, A. N. (2019). Analisis Kemampuan Pemecahan Masalah Matematika Ditinjau dari Motivasi Belajar Siswa Berdasarkan Gender. Imajiner: Jurnal Matematika Dan Pendidikan Matematika, 1(6), 373. https://doi.org/10.26877/imajiner.v1i6.4867

Hardianto, \& Baharuddin, M. R. (2019). Efektifitas Penerapan Model Pembelajaran PAIKEM Gembrot terhadap Peningkatan Hasil Belajar Mahasiswa pada Mata Kuliah Pembelajaran Matematika Sekolah Dasar. Cokroaminoto Journal of Primary Education, 2(1), 27-33. https://doi.org/10.30605/cjpe.212019.105

Karmiani, S. (2018). Penggunaan Media Komik Berbahasa Inggris Sebagai Upaya Meningkatkan Kemampuan Membaca Pemahaman Bahasa Inggris Pada Siswa Kelas Viii Smpn 3 Teluk Kuantan. JURNAL PAJAR (Pendidikan Dan Pengajaran), 2(6), 883. https://doi.org/10.33578/pjr.v2i6.6514

Khasanah, I. M., Nurhidayat, M., \& Ferawati, F. (2019). Studi Komparasi Penggunaan Media Pembelajaran Komik dengan Media Modul Pembelajaran pada Metode Resitasi Pada Hasil Belajar Fisika SMA. Radiasi : Jurnal Berkala Pendidikan Fisika, 12(2), 61-69. https://doi.org/10.37729/radiasi.v12i2.53

Kurniati, L. (2017). Pembelajaran Kontekstual Open Ended Problem Solving Dengan Komik Matematika Untuk Meningkatkan Keterampilan Pemecahan Masalah. Journal of Medives Journal of Mathematics Education IKIP Veteran Semarang, 1(1), 34-41.

Meidyawati, S., \& Ws, R. (2018). Pengaruh Penggunaan Media Komik Terhadap Hasil Membaca Pemahaman Di Kelas V Sd Negeri 2 Gunung Pereng Kota Tasikmalaya. PEDADIDAKTIKA: Jurnal Ilmiah Pendidikan Guru Sekolah Dasar, 5(2), 283-295.

Mery, D., Hidayat, C., \& Ihsan, I. R. (2020). Desain Pembelajaran Model Problem-Based Learning Terkait Kemampuan Berpikir Kreatif Matematis dan Adversity Quotient Peserta Didik. MATHEMA JOURNAL, 2(2), 1-9.

Mufarizuddin. (2018). Analisis Kesulitan Pembelajaran Matematika Siswa Kelas V Sd Negeri 012 Bangkinang Kota. Journal On Education, 1(1), 40-47.

Mujawal, W. A., Bani, A., \& Nani, K. La. (2018). Penggunaan Media Komik dalam Pembelajaran Matematika untuk Meningkatakan Motivasi dan Hasil Belajar Siswa pada Materi SPLDV. Jurnal Matematika Dan Pendidikan Matematika, 7(1), 1-14.

Mulyati, L. (2016). Penggunaan Media Komik Strip Dalam Meningkatkan. Jurnal Riksa Bahasa, 2(2), 189-190.

Musfiroh, D. (2018). Pengaruh Penggunaan Media Komik terhadap Keterampilan Bercerita Siswa Kelas V SD Negeri Sinduadi 1 Kecamatan Mlati Kabupaten Sleman Tahun Ajaran 2016/2017. Pendidikan Guru Sekolah Dasar.

Nugroho, A. A., \& Dwijayanti, I. (2019). Analisis Kemampuan Pemecahan Masalah Mahasiswa Calon Guru Matematika Pada Mata Kuliah Program Linier. EKSAKTA: Jurnal Penelitian Dan Pembelajaran MIPA, 1(2), 24-31.

Nugroho, B. S. (2018). Studi perbandingan penggunaan media berbasis komikdengan media Flipbook Maker ditinjau dari hasil belajar IPS siswa kelas V SD. Sereal Untuk, 51(1), 51.

Nuraeni, D., Azwar Uswatun, D., \& Nurasiah, I. (2020). Analisis Pemahaman Kognitif Matematika Materi Sudut Menggunakan Video Pembelajaran Matematika Sistem Daring Di Kelas Iv B Sdn Pintukisi. Pendas : Jurnal Ilmiah Pendidikan Dasar, V(Vol 5 No 1 June 2020), 61-75. https://doi.org/10.23969/jp.v5i1.2915

Nurfitriyanti, M., Rosa, N. M., \& Patimah, F. (2020). Adversity Quotient dan Locus of Control Serta Pengaruhnya Terhadap Kemampuan Pemecahan Masalah Matematika. Prosiding Seminar Nasional Sains, 1(1), 479-486. 
Prasetyo, E., \& Hardjono, N. (2018). Efektivitas penggunaan media pembelajaran permainan tradisional congklak terhadap minat belajar matematika (MTK) siswa sekolah dasar. Sereal Untuk, 51(1), 51.

Puspaningtyas, N. D. (2019). Berpikir Lateral Siswa SD Dalam Pembelajaran Matematika. MATHEMA JOURNAL, 1(1), 24-30.

Putri, L. A., \& Dewi, P. S. (2020). Media Pembelajaran Menggunakan Video Atraktif pada Materi Garis Singgung Lingkaran. MATHEMA JOURNAL, 2(1), 32-39.

Rahmah, K., Puspitorini, A., \& Musthafa, R. A. (2020). Analisis Kesulitan Siswa dalam Pemecahan Masalah Matematika Kelas XI IPA SMAN 2 Sumenep. 1(April), 97-105.

Ramadhani, W. P. (2019). Pengaruh Penggunaan Media Komik dan Motivasi Belajar terhadap Hasil Belajar Matematika Siswa SMP. JUPITEK: Jurnal Pendidikan Matematika, 2, 77-86.

Ramdhani, S. I., Magfirah, N., \& Hambali, H. (2020). pengaruh penggunaan media komik terhadap hasil belajar siswa pada materi virus kelas $X$ di SMA Negeri 2 gowa. Orphanet Journal of Rare Diseases, 21(1), 1-9. https://doi.org/10.1155/2010/706872

Ratumanan, T. G., \& Tetelepta, Y. (2019). Analisis Pembelajaran Matematika Berdasarkan Kurikulum 2013 Pada Sma Negeri 1 Masohi. JUMADIKA: Jurnal Magister Pendidikan Matematika, 1(1), 25-34. https://doi.org/10.30598/jumadikavol1 iss1 year2019page25-34

Rigusti, W., \& Pujiastuti, H. (2020). Analisis Kemampuan Pemecahan Masalah Ditinjau Dari Motivasi Belajar Matematika Siswa. Prima: Jurnal Pendidikan Matematika, 4(1), 1. https://doi.org/10.31000/prima.v4i1.2079

Rismen, S., Juwita, R., \& Devinda, U. (2020). Analisis Kemampuan Pemecahan Masalah Matematika Siswa Ditinjau dari Gaya Kognitif Impulsif. Jurnal Gantang, 5(1), 61-68. https://doi.org/10.31629/jg.v5i1.1579

Riwanto, M. A., \& Wulandari, M. P. (2018). Efektivitas Penggunaan Media Komik Digital (Cartoon Story Maker) dalam Pembelajaran Tema Selalu Berhemat Energi. Pancar, 2(1), 14-18. Retrieved from https://ejournal.unugha.ac.id/index.php/pancar/article/viewFile/195/160

Rohmawati, N. E., Pendidikan, S., Mandarin, B., Bahasa, F., Surabaya, U. N., Wibisono, G., \& Ed, M. (2017). Pengunaan Media Komik Berbahasa Mandarin Terhadap Keterampilan Membaca Pemahaman Bahasa Mandarin Siswa Kelas X Perhotelan SMK 17 Agustus 1945 Surabaya. 1-5.

Subroto, E. N., Qohar, A., \& Dwiyana. (2020). Efektivitas Pemanfaatan Komik sebagai Media Pembelajaran Matematika. Jurnal Pendidikan: Teori, Penelitian, Dan Pengembangan, 5(2006), 135-141. Retrieved from file:///C:/Users/LENOVO/AppData/Local/Temp/13156-19771-1-SM.pdf

Sugiartinengsih, R. (2018). Penggunaan Media Komik Strip dalam Meningkatkan Keterampilan Menulis Teks Ekplanasi di SMAN 1 Sukahaji. Riksa Bahasa, 2(2), 187-194.

Sulistiawati, I., Arsyad, N., \& Minggi, I. (2019). Deskripsi Penalaran Siswa dalam Pemecahan Masalah Matematika pada Pokok Bahasan Barisan dan Deret Ditinjau dari Kemampan Awal. Issues in Mathematics Education, 3(2), 111-118.

Suparmi, S. (2018). Penggunaan Media Komik Dalam Pembelajaran IPA di Sekolah. Journal of Natural Science and Integration, 1(1), 62-68. https://doi.org/10.24014/jnsi.v1i1.5196

Triandini, E., Jayanatha, S., Indrawan, A., Putra, G. W., \& Iswara, B. (2019). Metode Systematic Literature Review untuk Identifikasi Platform dan Metode Pengembangan Sistem Informasi di Indonesia. IJIS: Indonesian Journal of Information Systems, 1(2), 
63-77.

Winara, \& Haniyyah, U. (2019). Pengaruh Penggunaan Media Pembelajaran. 0-71. 